\title{
Mutations affecting the stability of the fushi tarazu protein of Drosophila
}

\author{
Kathryn A. Kellerman, ${ }^{1}$ Dianne M. Mattson, ${ }^{1}$ and Ian Duncan ${ }^{2}$ \\ Department of Biology, Washington University, St. Louis, Missouri 63130 USA
}

\begin{abstract}
We present a molecular analysis of four dominant alleles of the pair-rule gene $f t z$. Three of these, the $f t z$ Ual alleles, cause anti-ftz segmentation defects and homeotic transformations of the first abdominal segment to the third. These alleles are shown to be missense changes affecting two nearby proline codons. Embryos homozygous for these mutations accumulate higher levels of $f t z$ protein than wild type and show strong persistence of $f t z$ protein, but not RNA. These effects appear to result from stabilization of the $f t z$ protein, since ftz stripes decay much more slowly in mutant embryos than in wild type after injection of the protein synthesis inhibitor cycloheximide. We trace the origin of segmentation defects in $f z^{\text {Ual }}$ embryos to repression of the pairrule gene even-skipped by excess ftz protein during stripe sharpening. Homeotic transformations are shown to be correlated with ectopic expression of the $a b d-A$ gene of the bithorax complex. A 12-amino-acid sequence containing the proline residues altered in the $f t z^{\text {Ual }}$ mutants appears to be conserved in the proteins encoded by other segmentation genes and the vertebrate oncogene myc and may target these proteins for rapid degradation. The fourth allele examined, $T(2 ; 3) f t z^{R p l}(R p \eta$, also causes homeotic transformations and is a translocation broken within the $f t z$-coding region. Both $f t z$ transcript and protein stripes are persistent in $R p l$ embryos, suggesting that the Rpl RNA is stabilized relative to wild type.
\end{abstract}

[Key Words: Segmentation genes; fushi tarazu; even-skipped; homeosis; protein stability]

Received June 8, 1990; revised version accepted August 21, 1990.

The fushi tarazu (ftz) gene of Drosophila is a pair-rule segmentation gene (Nüsslein-Volhard and Wieschaus 1980 ) that is expressed in a series of seven stripes at blastoderm (Hafen et al. 1984; Carroll and Scott 1985). These stripes play a key role in subdividing the embryo into parasegments, the fundamental units of insect segmentation (Martinez-Arias and Lawrence 1985; Patel et al. 1989a). By regulation of the segment polarity genes engrailed (en) (Howard and Ingham 1986; DiNardo and O'Farrell 1987; Lawrence et al. 1987) and wingless (wg) (Ingham et al. 1988), ftz stripes define the boundaries of even-numbered parasegments. In $\mathrm{ftz}^{-}$embryos, these boundaries fail to form, and structures from even-numbered parasegments do not develop (Nüsslein-Volhard et al. 1985). Odd-numbered parasegments are defined by the pair-rule gene even-skipped (eve), which is expressed in stripes that are complementary to those of $\mathrm{ftz}$ (Harding et al. 1986; Macdonald et al. 1986; Frasch and Levine 1987; Frasch et al. 1987). In addition to definition of parasegment boundaries, $f t z$ appears to play a central role in the parasegment-specific activation of the homeotic genes (Duncan 1986; Ingham and Martinez-Arias 1986; Ingham et al. 1986; Ish-Horowicz et al. 1989). The $\mathrm{ftz}$ protein contains a homeo domain and binds to DNA (Laughon and Scott 1984; Desplan et al. 1988; Laughon et al. 1988).

\footnotetext{
${ }^{1}$ These authors made equal contributions to this paper. ${ }^{2}$ Corresponding author.
}

In a previous report, (Duncan 1986), the genetic properties of three dominant gain-of-function alleles of $f t z$ were described. These alleles have two major phenotypes: They cause segmentation defects that are out of phase (anti-ftz) with respect to those caused by $f t z$ lossof-function alleles, and they cause homeotic transformations of the anterior first abdominal segment (Al) to the third (A3). Because the latter transformation superficially resembles those caused by the Ultra-abdominal mutants of the bithorax complex (Lewis 1978), these ftz alleles were called Ultra-abdominal-like, or Ual, alleles. Two lines of genetic evidence indicate that the basic defect in the Ual mutants is hyperactivity or overproduction of the $f t z$ protein. First, animals that carry extra doses of $f t z^{+}$, but are otherwise wild type, show both anti-ftz segmentation defects (I. Duncan, unpubl.) and transformations of Al to A3 (Duncan 1986). Second, the Ual mutants are themselves dosage sensitive: Ual hemizygotes are virtually wild type in phenotype, Ual + + animals show an intermediate phenotype, and Ual homozygotes are strongly affected.

Here, we present a molecular characterization of the Ual alleles. We describe the DNA sequence changes in the mutants and identify their primary defect as the stabilization of the $\mathrm{ftz}$ protein. We trace the origin of anti$f t z$ segmentation defects in the mutants to repression of eve by excess $\mathrm{ftz}$ protein during stripe sharpening. Although the underlying cause of homeotic transformations in the mutants is not identified, we show that the 
Ual alleles cause ectopic activation of the homeotic gene $a b d-A$ in the anterior first abdominal segment. Finally, we present a molecular analysis of $T(2 ; 3) f t z^{R p l}$ (RpI), a translocation broken at the $3^{\prime}$ end of the $f t z$ homeo box (Laughon and Scott 1984) that also causes homeotic transformations. Our analysis suggests that the truncated $R p l$ transcript is stabilized relative to wild type.

\section{Results}

$\mathrm{ft}^{\mathrm{Ual}}$ alleles are missense mutations

The Ual mutants all appear normal by Southern blotting. No restriction fragment length differences within the known $f t z$ regulatory or transcribed regions were seen between any of the mutants and their background alleles. Genomic libraries were constructed from stocks homozygous or hemizygous for each of the mutants and their wild-type background alleles and clones covering the $f t z$ transcribed region were isolated. Sequence analysis of these clones reveals that each of the Ual mutations differs from its wild-type background allele by a single base-pair change. As shown in Figure 1, the Ual mutants are all $\mathrm{C} \rightarrow \mathrm{T}$ transitions that affect two nearby proline codons. Ual1 causes an inferred substitution of leucine for Pro215 (numbering from Laughon and Scott 1984), Ual3 causes a substitution of serine for this same proline, and Ual2 causes a substitution of leucine for Pro211.

\section{$\mathrm{ftz}$ protein expression in Ual mutant embryos}

We followed $\mathrm{ftz}$ protein expression during embryogenesis of the Ual mutants and wild type using the mouse anti-ftz monoclonal antibody mAb DMftz.1 (see Materials and methods|. Early intermediates in the resolution of the seven-striped pattern of $f t z$ protein expression (Karr and Kornberg 1989) are seen easily after staining with this antibody and appear normal in the Ual mutants, although the mutants stain more intensely than wild type at all stages. As in wild type,

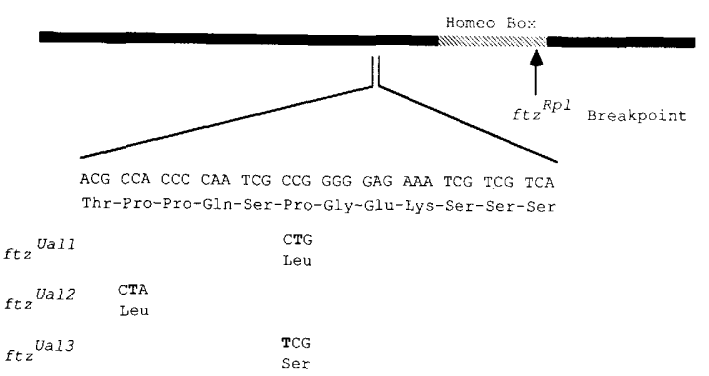

Figure 1. Sequence changes in the $f t z^{U a l}$ alleles. The $f t z$-coding sequence is shown as a bar, with the homeo box indicated by hatching. The sequence containing the $f t z^{U a l}$ mutations is expanded to show nucleotide changes (boldface) and altered codons. The position of the $f t z^{R p l}$ translocation breakpoint is indicated by an arrow. stripes are broad at first and have diffuse borders; these stripes then narrow and sharpen at their borders /see Fig. 2). After sharpening, stripes in the Ual mutants are wider than in wild type at this stage. During germ-band extension, staining persists in the Ual mutants and does not undergo the rapid fading seen in wild type; indeed, $f t z$ stripes appear to widen as germ-band extension proceeds. Epidermal staining in the mutants persists until well after the completion of germ-band extension. In Ual2, the strongest of the mutants, epidermal staining fades out during stage 11 (Campos-Ortega and Hartenstein 1985), $\sim 2 \mathrm{hr}$ later than in wild type. During stage 11 , it becomes clear that the limits of persistent $f t z$ stripes in the $U a l$ mutants coincide precisely with parasegmental grooves.

In both mutant and wild-type embryos, neural expression of $f t z$ protein (Carroll and Scott 1985) becomes visible at the beginning of stage 10. Although there is no detectable temporal overlap between epidermal and neural expression in wild type, these expression modes overlap for a period of $\sim 13 / 4 \mathrm{hr}$ in Ual2. Moreover, unlike wild type, Ual mutant embryos show a strong pair-rule modulation of early neural expression: Neural cells in even-numbered (ftz-expressing) parasegments stain precociously relative to those in odd-numbered parasegments. This observation suggests that $f t z$ transcription in the nervous system may be enhanced by $f t z$ protein persisting from the zebra-stripe stage [although previous tests of $f t z$ autoregulation in the nervous system have been negative (Hiromi and Gehring 1987; Dearolf et al. 1989)|. In addition, an irregular pattern of large, darkly staining cells is seen in the epidermis of even-numbered parasegments in the Ual mutants (Fig. 2h, arrow). Although the fate of these cells is not known, their relatively rapid disappearance from the epidermis suggests they may sink internally and participate in formation of the nervous system. Despite these early differences, the pattern of neural staining at later stages appears normal. At all stages, neural staining is more intense in the Ual mutants than in wild type.

$\mathrm{ftz}$ protein is more abundant in Ual mutant embryos than in wild type

The intense staining of $U a l$ mutant embryos relative to wild type suggests that the mutants accumulate higher levels of $f t z$ protein. To determine $f t z$ protein amounts we used the polyclonal anti-ftz antisera of Krause et al. (1988) to probe Western blots of proteins from mutant and wild-type embryos (Fig. 3). These experiments reveal that in 2.75- to 3.25-hr-old embryos, ftz protein levels are $~ 1.3$-fold greater than wild type in Ual1 homozygotes, 2.7-fold greater in Ual2 homozygotes, and 2.0-fold greater in Ual3 homozygotes. Repeat experiments using independent embryo collections gave increases of 1.1fold for Ual1, 2.9- and 2.7-fold for Ual2, and 1.7-fold for Ual3. These levels of $f t z$ protein correlate well with the severities of the Ual mutants; Ual2 has the most extreme phenotype, and Ual1 has the weakest (Duncan 1986). 
Figure 2. $f t z$ protein staining in wild-type and Ual2/Ual2 embryos. (a-d) Wild-type embryos; $(e-h)$ Ual2 homozygotes. At blastoderm, wild-type $(a)$ and mutant $(e)$ patterns are similar, although stripes stain more darkly and are slightly wider in the mutant. By mid-germ-band extension, stripes have largely faded in wild type $\langle b|$ but continue to stain intensely in the mutant $|f|$. Slightly later, stripes appear to widen in mutant embryos relative to earlier stages /cf. arrowheads in $f$ and $g$ ), whereas stripes in wild type continue to fade $(c)$. At full germ-band extension, stripes fade out completely in wild type and expression in the nervous system begins (d). In Ual2 embryos, stripes persist into the neural round of expression $(h)$. Note the precocious development of neural staining in even-numbered (ftz-expressing) parasegments and the presence of darkly staining cells in the epidermal layer (arrow).

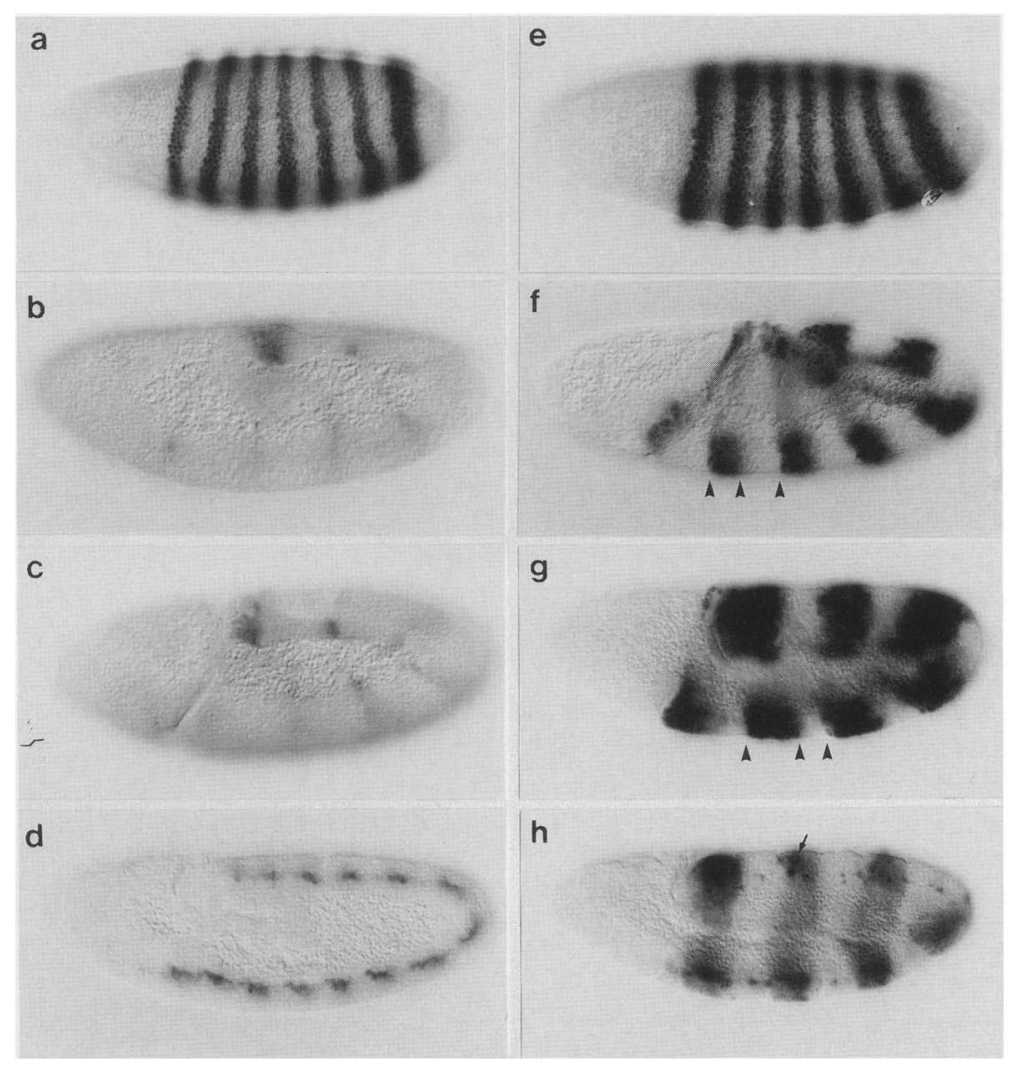

\section{Weak persistence of the Ual mutant transcripts}

To determine whether the changes in $f t z$ protein expression described above are also seen at the RNA level, we characterized $f t z$ transcripts in the $U a l$ mutants by in situ hybridization. As shown in Figure 4, $f t z$ transcript stripes are only slightly more persistent in the $U a l ~ m u-$ tants than in wild type, indicating that strong $f t z$ protein persistence in these mutants does not result from increased mRNA stability or from continued transcription (cf. Fig. 2c,g with Fig. 4c,f). The slight increase in transcript persistence seen may result from autoregulation, as Hiromi and Gehring (1987) and Dearolf et al. (1989) demonstrated that $\mathrm{ftz}$ transcription is enhanced by $\mathrm{ftz}$ protein in epidermal cells. ftz transcript stripes also appear to be slightly wider in the Ual mutants than in wild type during germ-band extension. Pronounced pair-rule modulation of $f t z$ transcript accumulation occurs during early neural expression in Ual embryos, although such modulation is also seen weakly in wild type (data not shown).

\section{The Ual mutant proteins appear to have longer half- lives than wild type}

To determine whether persistence of $f t z$ protein in the Ual mutants results from reduced susceptibility to degradation, we followed $f t z$ protein staining in blastoderm embryos after injection of the protein synthesis inhibitor cycloheximide. Blastoderm embryos were injected at mid-stage 5 (Campos-Ortega and Hartenstein 1985), incubated for varying times, and then fixed and stained for $f t z$, as described in Materials and methods. Stained wildtype and Ual2 mutant embryos fixed at successive times after injection are shown in Figure 5. The visual impression is that $f t z$ protein decay is biphasic in wild type; staining declines very rapidly immediately after injection, but is relatively stable after $\sim 10 \mathrm{~min}$, so that weak stripes are still present even $1 \mathrm{hr}$ after injection. In contrast, Ual2 mutant embryos show a gradual, apparently monophasic, decay in $\mathrm{ftz}$ protein staining after cycloheximide injection.

We quantitated the decay in $f t z$ protein staining in embryos injected with cycloheximide by measuring optical densities of photographic negatives (Fig. 6). In Figure 6a, we demonstrate that the film used responds approximately linearly in the range of optical densities measured. Figure $6 \mathrm{~b}-\mathrm{d}$ shows semilog plots of $\mathrm{ftz}$ stripe optical density versus time after injection for wild type and each of the Ual mutants. In wild type, ftz stripe decay is biphasic; immediately after injection, the halflife of decay is $\sim 6 \mathrm{~min}$; however, the half-life increases to $\sim 40 \mathrm{~min} 10-20 \mathrm{~min}$ after injection,. The initial rapid decay rate is consistent with Edgar et al. (1987), who estimated that $f t z^{+}$protein decays with a half-life of $<10$ min. However, these authors did not see a second slow phase of decay, presumably because their antibody detection was not as sensitive as ours. In contrast to wild type, $f t z$ stripes in the Ual mutants have half-lives of $38-42 \mathrm{~min}$ and decay in a monophasic fashion. It is un- 


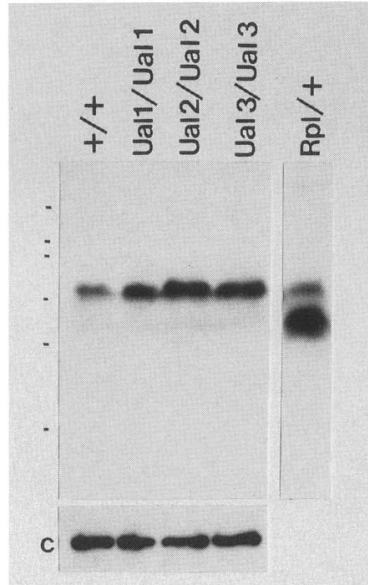

Figure 3. Relative $f t z$ protein concentrations in wild-type, Ual, and Rpl embryos. A Western blot of lysates from 2.75- to $3.25-\mathrm{hr}$ embryos probed with rabbit anti-ftz antibody and ${ }^{125} \mathrm{I}-$ labeled protein $\mathrm{A}$ is shown. For the Ual mutants, counts were normalized to cytoplasmic myosin control bands (C). Embryos used in the $R p l /+$ lane were from $T(2 ; 3) f t z^{R p l} / T(2 ; 3)$ $A n t p^{N S+R C 8}$ parents and were therefore of mixed genotype. The upper band in this lane is of the same molecular weight as wild-type $f t z$ protein; the lower band is presumably the truncated protein encoded by $R p l$. Dashes indicate positions of molecular mass standards of $205,116,97.4,66,45$, and $29 \mathrm{kD}$.

likely that our results in these experiments are complicated by incomplete blockage of translation because essentially identical results have been obtained for wild type after injection of 10 -fold greater amounts of cycloheximide (data not shown).

\section{Origin of segmentation defects in the Ual mutants}

Ual mutant larvae and adults show segmentation defects that are out of phase with those caused by ftz loss- of-function alleles (Duncan 1986). To determine when these defects first appear in embryogenesis, we stained Ual mutant embryos with antibodies against the eve and en proteins, as well as with anti-ftz antibodies. In normal development the eve protein is expressed in oddnumbered parasegments in a pattern that is essentially complementary to that of $f t z$ (Frasch and Levine 1987; Frasch et al. 1987), whereas en expression is restricted to the posterior compartment (anterior edge) of each parasegment (DiNardo et al. 1985; Fjose et al. 1985; Kornberg et al. 1985).

The first evidence of abnormality seen in Ual mutant embryos is at late blastoderm during the sharpening of $f t z$ and $e v e$ stripes. In normal development, $f t z$ and $e v e$ stripes are broad prior to sharpening and have diffuse borders that overlap (see Fig. 7a). These stripes then narrow and develop sharp boundaries as the expression of each gene is extinguished in single rows of cells in the regions of overlap (Frasch and Levine 1987; Frasch et al. 1988) (Fig. 7b). In wild type, ftz and eve stripes narrow to the same extent during sharpening and so remain equal in width. However, in Ual2 homozygotes, eve stripes become much narrower than $\mathrm{ftz}$ stripes during sharpening (cf. Fig. 7c and d). Indeed, it would appear that stripe sharpening in Ual2 homozygotes occurs almost entirely by loss of eve expression, with $f t z$ stripes remaining almost at their presharpening width. The spacing of en stripes during germ-band elongation in Ual2 embryos indicates that the parasegments defined by the sharpened eve stripes are also narrower than normal, whereas those defined by the $f t z$ stripes are abnormally wide (see arrowheads in Fig. 8a). In situ hybridization experiments show that wg stripes, which are located just anterior to en stripes (Baker 1987; Ingham et al. 1988), are similarly displaced (data not shown).

In wild type, $f t z$ stripes fade rapidly from their posterior edges during germ-band extension (Fig. 2b). However, in Ual2 homozygotes $\mathrm{ftz}$ protein staining appears

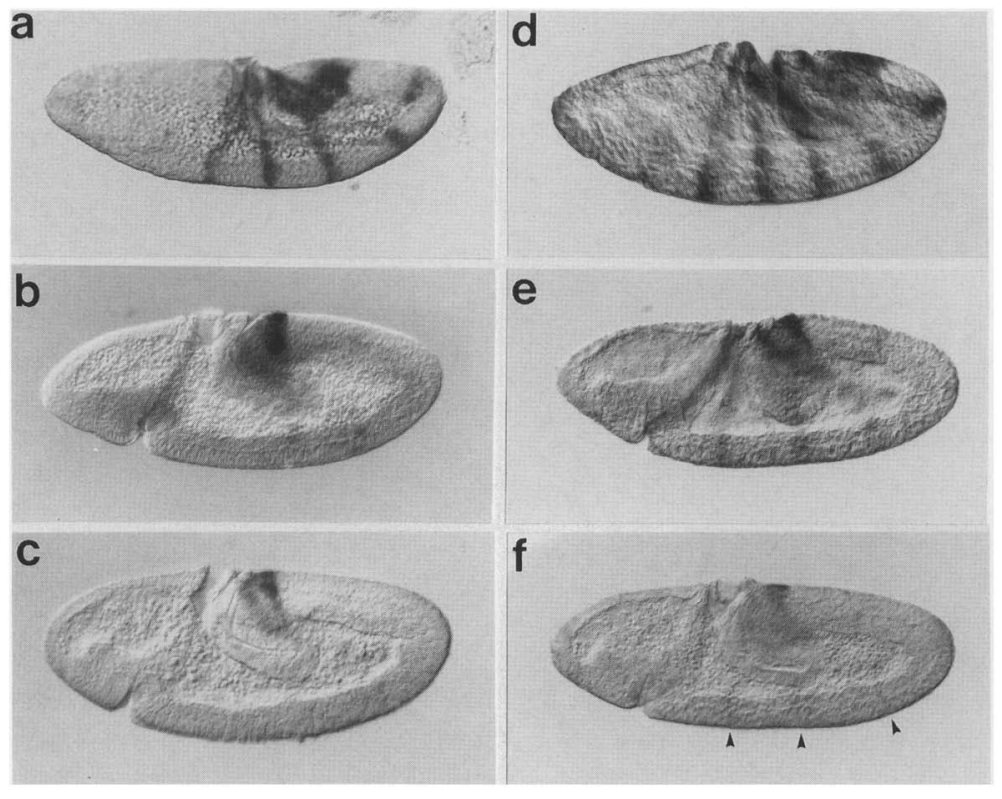

Figure 4. In situ hybridization to ftz transcripts in wild-type and $f t z^{\text {Ual2 }}$ mutant embryos. Embryos were hybridized with digoxigenin-labeled $f t z$ probe, which was detected immunohistochemically with alkaline phosphatase-conjugated anti-digoxigenin antibody. $(a-c)$ Wild-type; $(d-f)$ Ual2 embryos. Transcript stripes are prominent in both wild-type and Ual2 embryos from blastoderm through early gastrulation $(a, d)$, but fade rapidly during germ-band extension $(b, e)$. Stripes disappear completely by late stage $8\langle c, f)$ or early stage 9 . Note that stripes are wider and slightly more intense in Ual2 than in wild type at each stage. Arrowheads in $f$ indicate stripes present in Ual2 but absent from the same stage in wild type $(c)$. 
Figure 5. $f t z$ staining of embryos at successive times after injection of the protein synthesis inhibitor cycloheximide. Wild-type and Ual2 embryos were injected with cycloheximide at blastoderm and fixed at $0,10,20,40$, and 60 $\mathrm{min}$ after injection, as indicated. Note that in wild type, staining declines rapidly during the first $10 \mathrm{~min}$ after injection and then stabilizes; in Ual2 embryos, staining shows a more uniform gradual decline. The regular cortical arrangement of blastoderm nuclei breaks down between 10 and $20 \mathrm{~min}$ after injection, resulting in a grainy appearance of the $f t z$ stripes.

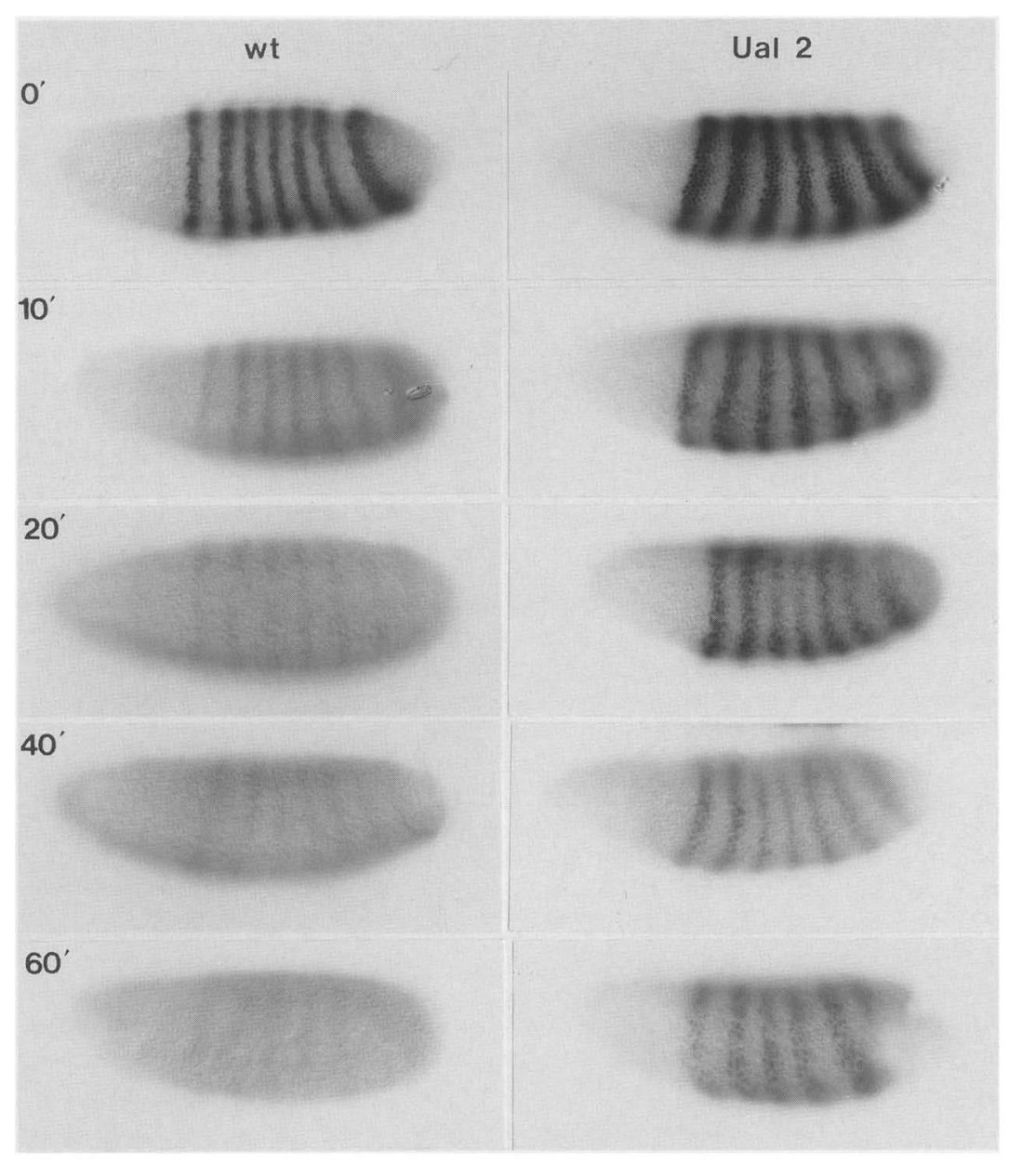

to increase in the posterior of each stripe at this stage. As a result, ftz staining becomes uniform, or nearly so, within even-numbered parasegments /cf. Figs. $2 \mathrm{~g}$ and 8b). One explanation for this apparent increase in staining at the posterior of each stripe could be that, in Ual2 homozygotes, residual $\mathrm{ftz}$ protein remains throughout each even-numbered parasegment at the start of germ-band extension. Because $f t z$ is known to be autoregulated in epidermal cells (Hiromi and Gehring 1987; Dearolf et al. 1989), this residual protein could cause abnormal activation of further $f t z$ transcription during germ-band extension. If autoregulation were to play such a role, we reasoned that a transformed $\mathrm{ftz} / \boldsymbol{\beta}$ galactosidase reporter construct should be similarly activated in a Ual2 mutant background. To test this, we constructed $\mathrm{ftz}^{+}$and Ual2 stocks homozygous for the $\mathrm{P}\left[\mathrm{ry}^{+}, \mathrm{ftz} / \mathrm{lacC}\right]$ construct of Hiromi et al. (1985) inserted into the second chromosome. We were surprised to find that after germ-band extension, $\beta$-galactosidase stripes expand to fill even-numbered parasegments in both $\mathrm{ftz} \mathrm{z}^{+}$ and Ual2 embryos (data not shown).

An additional abnormality seen in Ual2 homozygotes is the formation, after germ-band extension, of partial ectopic en stripes in odd-numbered (eve-expressing) parasegments (Fig. 8c, arrowheads). These ectopic stripes, which never occur in wild type, usually form dorsally and laterally, although occasionally they are complete ventrally as well. They are highly dynamic and, in late germ-band-extended embryos, often fuse partially with posterior-adjacent (even-numbered) en stripes, especially in lateral and dorsal regions. By late germ-band extension, parasegment sizes appear to be largely normalized. However, at this stage, gaps are often seen dorsally in even-numbered en stripes. Although we do not have a clear picture of how these gaps arise, possible intermediates suggest that they may occur when ectopic en stripes fuse with both anterior- and posterior-adjacent neighbors. By germ-band retraction, many embryos are nearly normal with respect to en staining, although many ectopic stripes and gaps persist (see Fig. 8d) and are presumably responsible for the segmentation defects seen in Ual mutant larvae and adults (Duncan 1986).

\section{Homeotic transformations}

The major segmental transformation seen in the $U a l$ mutants is of the anterior first abdominal segment [located in parasegment (PS) 6] to anterior third abdominal segment (located in PS8) (Duncan 1986). Because PS8 identity is defined by the $a b d-A$ gene of the bithorax complex (Sánchez-Herrero et al. 1985; for review, see Duncan 1987), it seemed likely that this transformation 

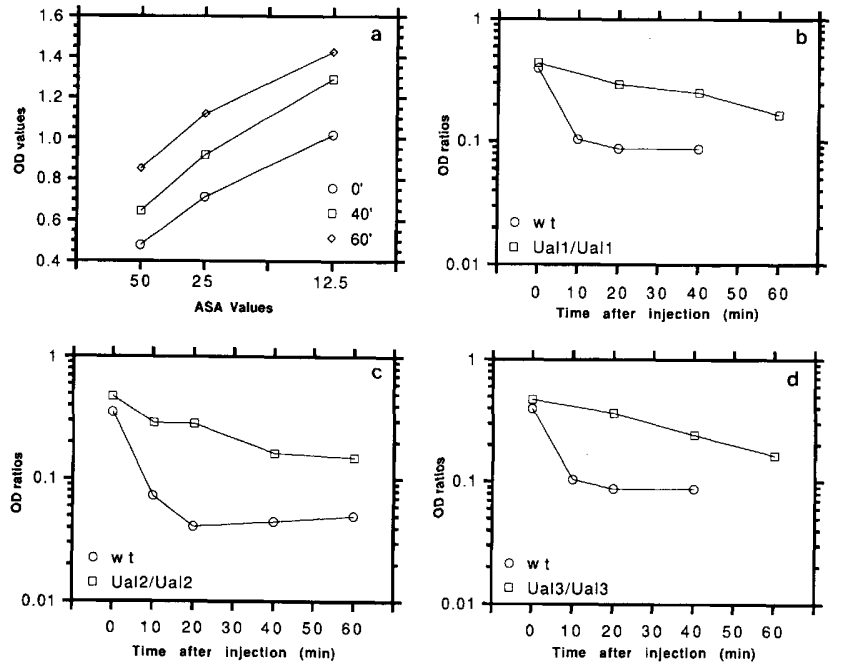

Figure 6. Quantitative analysis of $\mathrm{ftz}$ staining decay after cycloheximide injection. Staining intensities were quantitated by measuring optical densities (ODs) of photographic negatives, as described in Materials and methods. (a) The film used responds approximately linearly in the range of ODs measured in these experiments. Single embryos from the 0-, 40-, and 60-min time points in the Ual3 injection series were each photographed at ASA settings of 50,25 , and 12.5 on the exposure meter, and the ODs of the first $f t z$ stripes were plotted vs. exposure. The range of $\mathrm{OD}$ values measured here encompasses the highest and lowest OD values obtained in the analyses presented in $b-d$. $(b-d)$ Staining decay curves for wild-type and Ual1, Ual2, and Ual3 embryos calculated from negatives taken at a setting of ASA 25 on the exposure meter. The data presented in $c$ are derived from the negatives used in Fig. 5. Note that $b$ and $d$ are from the same experiment and share the same wild-type control. Also note that the ordinate values are in units of absolute OD in $a$, whereas in $b-d$, these values are OD ratios and thus have no units (see Materials and methods). In the first $10 \mathrm{~min}$ after injection, the half-life of staining decay in wild type is $\sim 5$ or $6 \mathrm{~min}$. Half-lives in the $\mathrm{Ual}$ mutants are all between 38 and $42 \mathrm{~min}$.

results from ectopic expression of $a b d-A$ in PS6. To monitor $a b d-A$ expression, we isolated a monoclonal antibody, mAb DMabd-A.1, which recognizes the $a b d-A$ protein. Staining with this antibody reveals that $a b d-A$ protein first becomes visible in wild type at the extended germ-band stage and labels a continuous block that includes most of the abdomen. Anti-abd- $A$ and anti-en double labeling shows that the anterior limit of $a b d-A$ expression coincides with the anterior boundary of PS7, whereas the posterior limit lies within PS13 (Fig. 9a). Although we cannot rule out the possibility that $a b d-A$ expression extends weakly to the posterior edge of PS13, staining appears to fade out somewhere within the anterior compartment of this parasegment. After germ-band retraction, the anterior limit of $a b d-A$ expression in the epidermis continues to lie at the anterior edge of PS7, whereas the posterior limit appears to retract to the en stripe of PS13. Although a few cells in the en stripe of PS6 occasionally begin to label for $a b d-A$ after germband retraction in wild type (see arrow in Fig. $9 b$ ), epi- dermal labeling is never seen in the anterior compartment of PS6.

The early pattern of $a b d-A$ expression in Ual2 homozygotes appears normal. However, after germ-band retraction, most embryos show some $a b d-A$ staining in the epidermis of both anterior and posterior compartments of PS6 (Fig. 9c). Thus, Ual2 causes ectopic expression of $a b d-A$ in PS6, although at a much later time in development than envisioned previously (Duncan 1986). The expression of $a b d-A$ in PS6 in Ual2 is primarily lateral, perhaps explaining why we do not see transformation of the A1 ventral setal belt in Ual mutant embryos. The posterior limit of $a b d-A$ expression appears to be normal in Ual2 homozygotes.

\section{$\mathrm{T}(2 ; 3) \mathrm{ftz}{ }^{\mathrm{Rpl}}$ : abnormal persistence of $\mathrm{ftz} R N A$}

The basic properties of $T(2 ; 3) f t z^{R p l}(R p l)$ have been described previously (Weiner et al. 1984; Duncan 1986). When heterozygous with wild type, Rpl frequently causes patchy transformations of posterior haltere to posterior wing. Rarely, patchy transformations of the first abdominal segment to a more posterior segment are also seen. $R p l$ homozygotes die as mature embryos that show defects in even-numbered ( $f t z$-expressing) parasegments. The $R p l$ translocation truncates the $f t z$-coding sequence near the carboxy-terminal end of the homeo box and, in the inferred protein sequence, replaces the carboxy-terminal 100 amino acids of the wild-type protein with a sequence of 10 amino acids encoded by unrelated DNA (Laughon and Scott 1984). It has been suggested (Duncan 1986) that the transformation of posterior haltere to wing may occur because the $R p l$ protein is defective and occasionally fails to activate high-level expression of the homeotic gene $U b x$.

In situ hybridization and antibody staining reveal that stripes of both ftz RNA and protein are strongly persistent in $R p l$ homozygotes (data not shown). Although staining of RNA and protein fades from the posterior of each stripe during germ-band elongation, some ftz protein is detectable throughout each even-numbered parasegment even after the completion of extension. Epidermal staining of $f t z$ protein does not persist as long as that in Ual embryos and fades out just prior to the start of $f t z$ expression in odd-numbered parasegments in the nervous system. As in the Ual mutants, neural expression is precocious in even-numbered parasegments, perhaps because of autoregulatory activation by residual $f t z$ protein. Western blotting experiments show that the $R p l$ protein is about fourfold more abundant than $\mathrm{ftz}^{+}$ protein in $2.75-$ to $3.25-\mathrm{hr}$ embryos from $\mathrm{Rpl} /+$ parents (see Fig. 3).

Probably the simplest explanation for persistence of both $f t z$ RNA and protein in $R p l$ embryos is that the $R p l$ transcript is stabilized relative to wild type. The $f t z^{+}$ RNA is highly unstable, having a half-life of between 7 and 14 min during nuclear cycles 13 and 14 (Edgar et al. 1986). Although the sequences targeting the $f t z$ transcript for rapid degradation are not known, the $3^{\prime}$ end (see Laughon and Scott 1984) contains a match at 7 of 8 

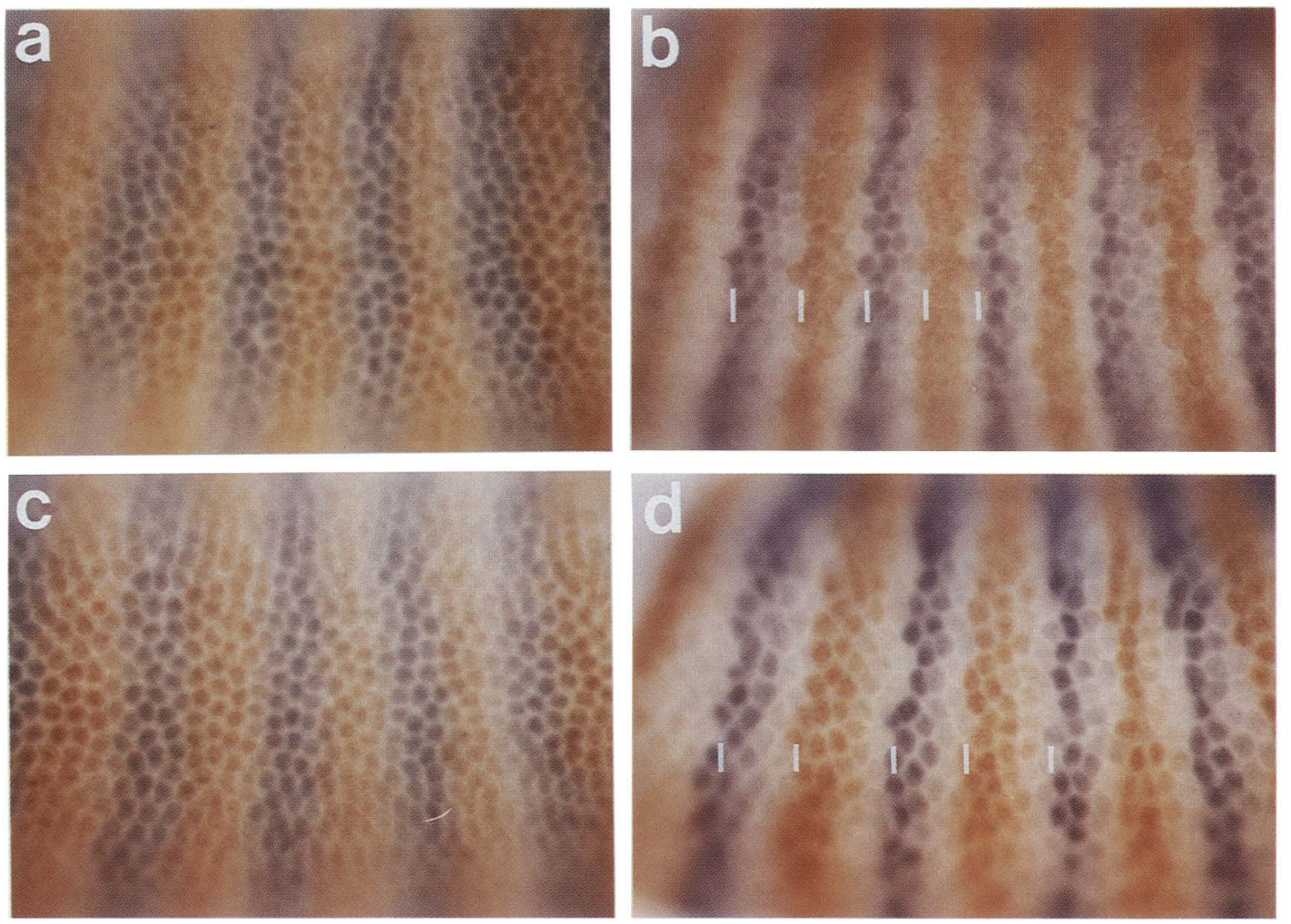

Figure 7. Stripe sharpening in wild-type $\langle a, b\rangle$ and $U a l 2\langle c$, and $d\rangle$ embryos. Embryos are double-labeled for $f t z$ protein (orange) and eve protein (purple). In wild type, $f t z$ and eve stripes are equal in width both before $(a)$ and after $(b)$ stripe sharpening. Note that stripes overlap in $a$ and that $f t z$ and $e v e$ appear to be extinguished in regions of overlap during sharpening. In Ual2 embryos, the early striping pattern $(c)$ appears to be normal. However, after sharpening $(d)$, ftz stripes are wider and eve stripes are narrower than in wild type. The white vertical bars in $b$ and $d$ mark the sharpened anterior edges of $f t z$ and $e v e$ stripes. Note the equal spacing in $b$ and the unequal spacing in $d$.

nucleotides to the UUAUUUAU consensus sequence described by Caput et al. (1986), which may target a number of mammalian transcripts for rapid degradation (Shaw and Kamen 1986; Wilson and Treisman 1988). The $R p l$ transcript must lack this sequence because the translocation breakpoint lies in a more $5^{\prime}$ position. Although increased RNA stability seems to be the most likely explanation for the persistent striping in $R p l$ embryos, we cannot rule out the possibility that $f t z$ transcription is prolonged in $R p I$ or that $f t z$ protein stability is also increased.

In addition to persistence of $f t z$ stripes during germband extension, we find that the evolution of the $f t z$ striping pattern at blastoderm is much retarded in Rpl embryos. For similar stages of membrane ingrowth, $f t z$ protein and RNA stripes are far less resolved in $R p l$ than in wild type. Because we do not see any marked delay in stripe resolution in the $U a l$ mutants, which stabilize the $f t z$ protein, these observations suggest that rapid turnover of RNA, and not protein, is of key importance during stripe formation.

$R p l$ embryos also show pattern abnormalities not obviously attributable to increased RNA stability. In homozygotes, the first and sixth stripes are significantly reduced compared to the other stripes and, in both homozygotes and heterozygotes, we see bilateral patches of $f t z$ protein expression dorsolaterally in the head region. It is not clear whether these head patches result from altered transcriptional control of $f t z$ or are a normal aspect of $f t z$ expression not detected previously because of the extreme instability of the ftz RNA (Edgar et al. 1986). Other pair-rule genes are expressed in the same region (Ingham et al. 1985; Kilchherr et al. 1986; Gergen and Butler 1988).

\section{Discussion}

\section{Ual alleles stabilize the $\mathrm{ftz}$ protein}

In this report, we show that the $U a l$ alleles are all missense mutations affecting two proline residues located 5 amino acids apart in the 413-amino-acid $f t z$ protein. Two of the alleles cause proline to leucine changes, whereas one causes a proline to serine change. Two lines of evidence indicate that the basic defect in these mutants is the stabilization of the $f t z$ protein. First, we find that the epidermal $\mathrm{ftz}$ protein persists $\sim 2 \mathrm{hr}$ longer in the Ual mutants than in wild type, although $f t z$ transcripts disappear at an almost normal rate. Second, we find that after injection of the protein synthesis inhibitor cycloheximide, $\mathrm{ftz}$ staining decays severalfold slower in the Ual mutants than it does in wild type. 


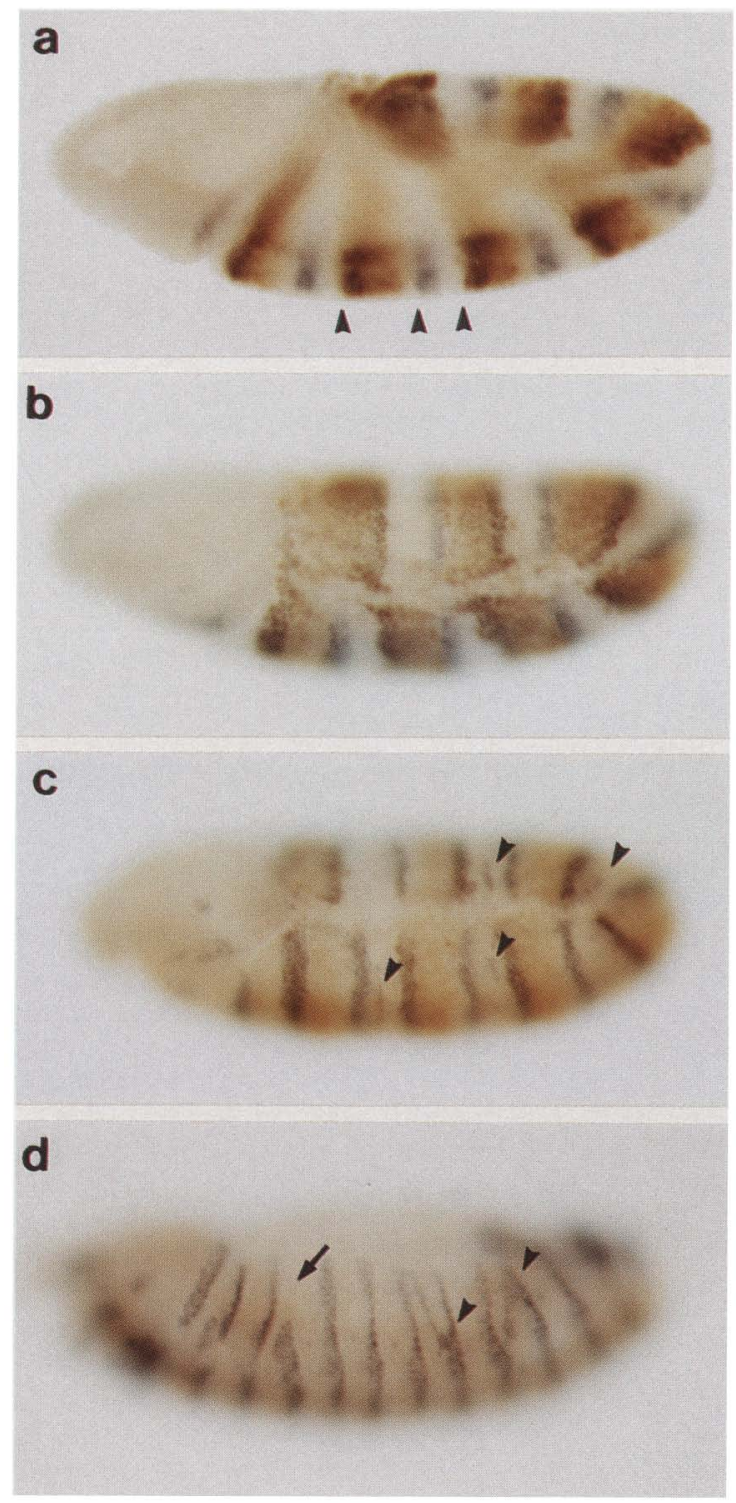

Figure 8. Segmentation in Ual2 embryos after gastrulation. All embryos are double-labeled for $f t z$ (orange) and en (gray). The en stripes identify the anterior edge of each parasegment. (a) An embryo early in germ-band extension. As indicated by arrowheads, even-numbered (ftz-expressing) parasegments are wider than odd-numbered parasegments. $f t z$ staining is strong and uniform in the anterior $3 / 4$ of each even-numbered parasegment but is weaker in the posterior quarter. In embryos nearing the completion of germ-band extension $(b), f t z$ staining becomes uniform, or nearly so, within even-numbered parasegments. In fully extended embryos $(c)$, ectopic en stripes often form medially in odd-numbered parasegments (see arrowheads). During and after germ-band retraction $(d)$, these ectopic en stripes usually fuse with posterior adjacent (even-numbered) en stripes (see arrowheads). Gaps often form in the even-numbered en stripes (arrow), perhaps as a result of fusion with ectopic en stripes.

Consistent with an increase in stability, higher levels of $f t z$ protein accumulate at blastoderm in the $U a l \mathrm{mu}$ tants than in wild type.

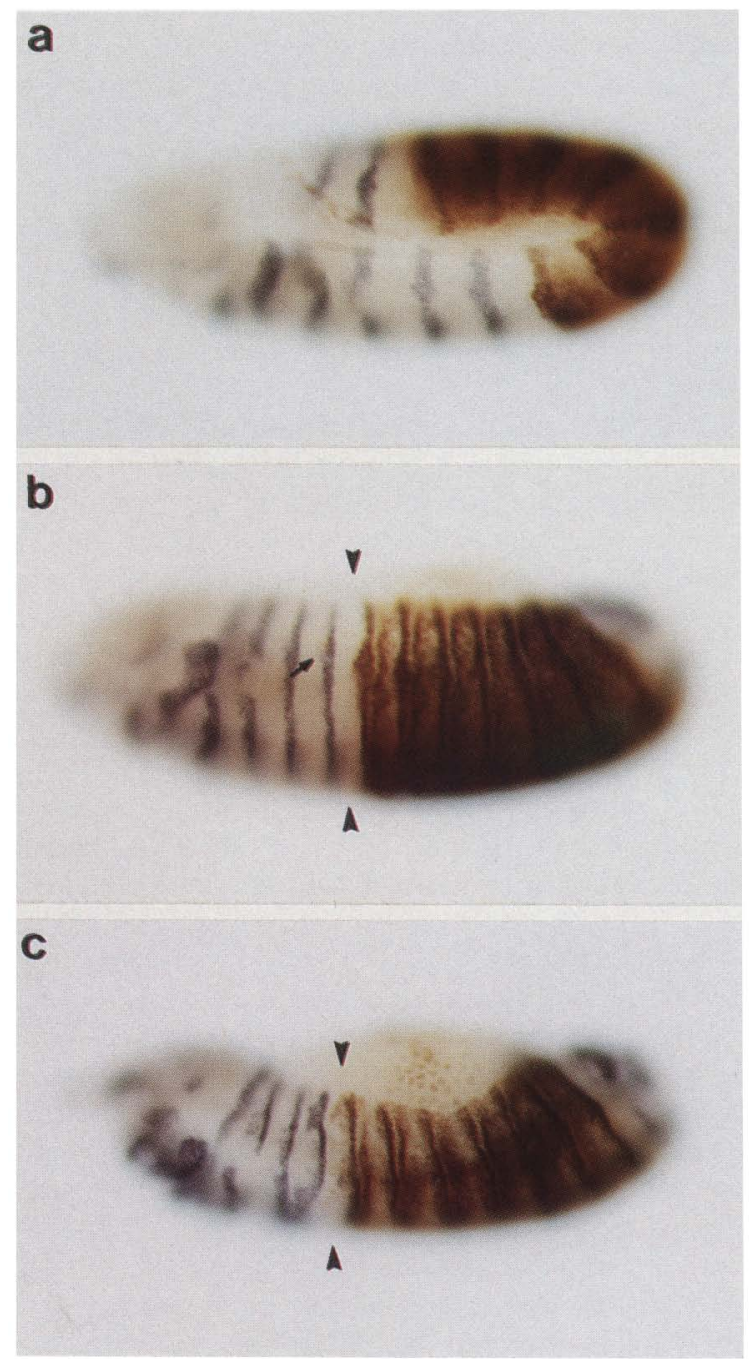

Figure 9. Expression of $a b d-A$ protein in wild-type and Ual2 embryos. All embryos are double-labeled for $a b d-A$ (brown) and en (gray). (a) Wild-type embryo during germ-band retraction. The anterior limit of $a b d-A$ expression coincides precisely with the en stripe of PS7. (b) Wild-type embryo after germ-band retraction. The anterior limit of $a b d-A$ expression is still coincident with the PS7 en stripe (the apparent extension of $a b d-A$ staining into PS6 in this embryo is due to internal, not epidermal, labeling). In both wild-type and Ual2 embryos, a group of cells within the en stripe of PS6 (marked by arrowheads) often begins to stain for $a b d-A$ after germ-band retraction (see arrow). (c) Ual2 embryo after retraction. As in most Ual2 homozygotes at this stage, $a b d-A$ staining is apparent in the epidermis of PS6 (arrowheads).

The $f t z$ proteins encoded by the $U a l$ mutants are not seriously impaired in essential functions; Ual mutant hemizygotes are almost wild type in phenotype and have full viability. This suggests that the region of the $f t z$ protein affected by the Ual mutations may function specifically to target the $f t z$ protein for rapid degradation. This region is very rich in the amino acids proline, glutamic acid, serine, and threonine. Rogers et al. (1986) and Rechsteiner (1988) have proposed that such "PEST" re- 
gions target eukaryotic proteins for rapid degradation. That all three of the Ual mutants alter one of the PEST amino acids would seem to support the PEST hypothesis. However, because most of the amino-terminal half of the $f t z$ protein is rich in the PEST amino acids, it is not at all clear according to the hypothesis why alteration of the prolines affected by the Ual mutants should have such a large effect on stability. Moreover, one of the mutants (Ual3) substitutes one PEST amino acid (serine) for another and would be expected to have little effect on stability.

Rather than amino acid composition, it may be the specific amino acid sequence in the region affected by the Ual mutants that determines $f t z$ protein stability. Computer searches indicate that a 12-amino-acid sequence containing the prolines altered in the mutants is conserved in the inferred protein sequences of at least three other Drosophila segmentation genes (see Fig. 10). These are the pair-rule genes eve (Macdonald et al. 1986; Frasch et al. 1987) and paired (prd) (Frigerio et al. 1986), and the gap gene hunchback (hb) (Tautz et al. 1987). A region showing similarity to the $f t z$ sequence is also present in the protein encoded by the myc oncogene (Watson et al. 1983). The best match is with the eve sequence, which is identical to $f t z$ at 8 of 12 positions and, like the $f t z$ sequence, is located amino-terminal to the homeo domain. Close matches to the $f t z$ sequence are also present in hunchback $(h b)$ and myc, whereas paired is more closely related to eve than it is to $f t z$. Both of the prolines affected by the $U a l$ mutants are at conserved positions within these sequences. Although stability measurements have been made only for $f t z$ (Edgar et al. 1987; this paper) and myc (Ramsay et al. 1984), rapidly changing expression patterns for the other genes suggest that all encode unstable proteins. Thus, the conserved region may function to target these proteins for rapid degradation. Alternatively, because all of the proteins in Figure 10 are also likely to be transcription factors, the conserved region may play some role in interacting with other nuclear proteins or DNA. It is worth noting that the $h b$ and myc sequences shown include matches to the $c d c 2$ protein kinase phosphorylation site consensus sequence (Moreno and Nurse 1990), suggesting that Ual alleles might stabilize the $f t z$ protein by altering its phosphorylation (see Krause and Gehring 1989).

The stabilization of the $f t z$ protein by the $U a l$ alleles could be quite indirect. For example, the $U a l$ mutations could stabilize $f t z$ protein by increasing its binding affinity for other molecules in the nucleus (for discussion of this mechanism, see Rechsteiner et al. 1987). The stabilization of $\mathrm{ftz}$ protein by such interactions may provide an explanation for our observation that decay of $f t z$ protein staining in wild type is biphasic after cycloheximide injection: A subpopulation of $\mathrm{ftz}^{+}$protein molecules could be protected from proteolysis by binding to other proteins or DNA. Alternatively, biphasic decay may occur because the degradation system responsible for rapid decay is itself unstable.

Although the proteolysis system involved in $\mathrm{ftz}$ degradation has not been identified, rapid degradation of $f t z$,

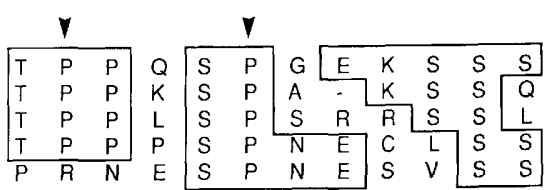

Figure 10. Sequence similarities between the region of $f t z$ protein affected by the $U a l$ mutants and regions of the proteins encoded by the Drosophila segmentation genes $h b$, eve, and prd, and the vertebrate oncogene myc. Computer searches reveal that in terms of amino acid identities, the best match in the NBRF protein data base to the $f t z$ sequence shown is in the eve protein. The eve sequence shows identity at 8 of 12 positions and, as in $f t z$, is located amino-terminal to the homeo domain. The two proline residues altered by the Ual mutations (see arrowheads) are at shared positions in these sequences. Many other proteins in the data base have regions showing identity at seven or fewer positions in the $f t z$ sequence. Because the sequence TPPXSP is present in the $f t z$ and eve sequences and contains the two prolines altered by the Ual mutations, we searched the data base for other proteins containing this sequence. Ten proteins (counting homologs as single proteins) were found. Of these, the three closest matches to the 12 amino-acid $f t z$ sequence are in the $e v e, h b$, and myc proteins. The remaining proteins in this group, most of which associate with nucleic acids, are the Antennapedia protein, jun, a fragment of the gag protein from baboon endogenous virus, human uracil-DNA glycosylase, the DNA-binding domain of bovine fibronectin, the E2 protein of human papillomavirus, and the tau microtubule-associated protein. Although prd shares only 5 amino acid identities with the $f t z$ sequence, it is included because of its similarity to the eve sequence $(6$ of 12 positions identical with two conservative differences) and because, like $f t z$ and eve, it is a pair-rule gene of Drosophila. The amino acid carboxy-terminal to the glutamine $|Q|$ in the $h b$ sequence is serine ( $\mathrm{S}$ ), so that even if a gap is not included, it is identical to the $f t z$ sequence at 7 of 12 positions. The $h b$ sequence shown includes residues 184-194 (Tautz et al. 1987), the myc sequence includes residues 61-72 from the chicken c-myc gene (Watson et al. 1983), the eve sequence includes residues 40-51 (Macdonald et al. 1986; Frasch et al. 1987), and the prd sequence includes residues 411-422 (Frigerio et al. 1986).

like most protein turnover, appears to be energy dependent (for review, see Rechsteiner 1987). We found (I. Duncan and D. Mattson, unpubl.) that injection of 2deoxy-D-glucose and sodium azide, which together cause ATP depletion in other systems (Hochster 1963; Fagan et al. 1986; Gronostajski et al. 1985), along with cycloheximide, blocks rapid $f t z$ protein degradation in wild type, although gradual decay continues to occur. That all three Ual mutations alter proline codons suggests that a proline endopeptidase (Andrews et al. 1982; Mentlein 1988; Yoshimoto et al. 1987; Pratt et al. 1987) might be involved in the rapid phase of $f t z$ degradation.

Finally, it should be noted that although the close proximity of the $\mathrm{Ual}$ alleles and their lack of effect on essential functions of the $\mathrm{ftz}$ protein are consistent with the idea that these mutants identify an instability domain, we have not ruled out the possibility that many amino acid changes stabilize the $f t z$ protein and that the $\mathrm{Ual}$ alleles are specific only in their lack of effect on essential functions. 


\section{Segmentation defects}

Stripe sharpening The first, and probably primary, segmentation defect we see in $\mathrm{Ual}$ mutant embryos is at blastoderm during $f t z$ and eve stripe sharpening. In wild type, $f t z$ and eve stripes narrow to the same extent so that they remain equal to one another in width. In Ual2 embryos, however, eve stripes narrow to a greater extent than $f t z$ stripes do. Because Ual2 causes the accumulation of approximately threefold higher levels of $f t z$ protein at blastoderm than wild type, this bias suggests that normal stripe sharpening depends on a balance between the amounts of $f t z$ and eve protein. Data to be presented elsewhere indicate that stripe sharpening involves the mutual repression of $f t z$ and eve in the regions of stripe overlap. Thus, genotypes in which $\mathrm{ftz}$ protein is in excess relative to eve protein (such as the $U a l$ mutants) show widening of $f t z$ stripes during sharpening, whereas genotypes in which eve protein is in excess show widening of eve stripes. A bias in favor of $f t z$ stripes similar to that seen in the Ual mutants appears to occur in embryos homozygous for weak eve alleles (Frasch et al. 1988). Very likely, this bias results from the reduced ability of the proteins encoded by these alleles to repress $f t z$ during sharpening. A requirement for $e v e^{+}$in the sharpening of $f t z$ stripes has been noted previously by Lawrence and Johnston (1989a,b).

Examination of the stages of membrane ingrowth at blastoderm reveals that stripe sharpening is not significantly delayed in Ual mutants. Initially, this observation seemed paradoxical because stabilization of the $f t z$ protein was expected to delay sharpening. The explanation appears to be that stripe sharpening in the $U a l \mathrm{mu}$ tants occurs primarily by decay of eve, and not $f t z$, protein. As a consequence, $f t z$ stripes remain at approximately their presharpening width, whereas eve stripes become abnormally narrow. In both wild-type and Ual2 embryos, sharpening is a two-step process, with gaps forming anterior to eve stripes before they form anterior to $f t z$ stripes (Frasch et al. 1988). We have not determined whether both of these phases are affected in the Ual mutants.

Anti-ftz segmentation defects superficially similar to those caused by the $U a l$ mutants occur when $f t z$ is expressed indiscriminately in the early embryo under the control of a heat-shock promoter (Struhl 1985; Ish-Horowicz and Gyurkovics 1988; Ish-Horowicz et al. 1989|. Although the end result is similar, Ish-Horowicz et al. (1989) have shown that the primary defect in heat-shock ftz embryos is quite different and involves alterations in en and wg expression not seen in the Ual mutants.

Germ-band extension In wild type, $f t z$ stripes become graded during gastrulation and germ-band extension so that the anterior of each stripe stains strongly and is sharply defined, whereas the posterior stains weakly and is of indefinite extent (Lawrence 1987; Lawrence et al. 1987; Lawrence and Johnston 1989a). Much significance has been attached to this gradient. For example, Frasch et al. (1988) have suggested that the segment polarity gene $e n$ is regulated so that it becomes expressed only at the high point of the gradient, at the anterior edge of each $f t z$ stripe. Lawrence and Johnston (1989a) have speculated that the $f t z$ gradient may provide positional information to other segment polarity genes as well. Our observations argue against these models because we find that in the $U a l$ mutants $e n$ is expressed at the anterior edge of each $\mathrm{ftz}$ stripe, just as in wild type, even though a normal gradient of $\mathrm{ftz}$ protein accumulation is not present. Although $\mathrm{ftz}$ staining in Ual2 embryos is transiently reduced in the posterior quarter of each stripe during sharpening, staining is maintained at a high level in the anterior $3 / 4$ of each stripe. During germ-band extension, staining increases in the posterior quarter and becomes uniform throughout each even-numbered parasegment. Because most even-numbered parasegments develop normally in the Ual mutants, our results suggest that the $f t z$ gradient may be entirely dispensable.

Although the distributions of $f t z$ protein and RNA are similar in Ual2 embryos at blastoderm and early germband extension, the increase in protein staining at the posterior of each stripe at later stages is not accompanied by an observable increase in ftz RNA. Likely, ftz transcripts are present here but at levels too low to detect. The posterior increase in $f t z$ protein staining appears to require functional $f t z$ protein, since a large number of $f t z$ loss-of-function alleles recovered as revertants of Ual2 show persistent but narrow $f t z$ protein stripes after germ-band extension (data not shown). This suggests that autoregulation may be an important component of posterior $f t z$ protein increase and argues against the possibility that diffusion of $f t z$ protein is responsible. We find that $\beta$-galactosidase staining in a $f t z / \beta$-gal transformant also increases to fill even-numbered parasegments during germ-band extension in both $\mathrm{ftz}^{+}$and Ual2 backgrounds. Thus, a posterior increase in $f t z$ protein during germ-band extension may be an aspect of normal development that has gone undetected because of the extreme instability of the wild-type protein and RNA. The posterior increase in staining also suggests that entire parasegments are domains of $f t z$ expression and lends support to models which specify that $f t z$ protein is involved in directing cell fates throughout even-numbered parasegments (e.g., Duncan 1986; Ingham and Martinez-Arias 1986; Ingham et al. 1988).

The extended germ band and germ-band retraction During germ-band extension, en expression appears to be essentially normal in Ual2 embryos, with the exception that stripe spacing is altered because of the widening of even-numbered parasegments. However, after the completion of extension, ectopic en stripes frequently appear dorsally in odd-numbered parasegments. The cause of these ectopic stripes is not clear. However, because $f t z$ does not seem to be expressed in odd-numbered parasegments (except at very early stages), it seems likely that they are an indirect consequence of parasegment narrowing. One possibility is that oddnumbered parasegments are often too small in the $U a l$ mutants to accommodate a complete repertoire of segment polarity gene expression patterns. Because ectopic 
en stripes occur in every parasegment in embryos mutant for the segment polarity gene patched (DiNardo et al. 1988; Martinez-Arias et al. 1988), one possibility is that ectopic en stripes arise in Ual2 embryos because of defective patched expression in narrowed parasegments. Like the ectopic en stripes in patched ${ }^{-}$embryos (DiNardo et al. 1988), those in Ual embryos are dynamic and fuse with adjacent stripes. The expression of $w g$, which may be expected to show ectopic activation in concert with en (DiNardo et al. 1988; Martinez-Arias et al. 1988), has not been examined at the extended germ-band stage in $\mathrm{Ual}$ mutants.

\section{Homeotic transformations}

In addition to segmentation defects, $\mathrm{Ual}$ mutants cause homeotic transformations of the anterior first abdominal segment (in PS6) to anterior third abdominal segment (in PS8) in the adult cuticle. In Ual2 homozygotes this transformation has almost $100 \%$ penetrance and expressivity. Because PS 8 identity is controlled by the $a b d-A$ gene of the bithorax complex (for review, see Duncan 1987), we examined $a b d-A$ protein expression in Ual2 mutant embryos. We find that in germ-band-extended embryos, $a b d-A$ protein expression is limited anteriorly by the PS7 anterior boundary, as in wild type. However, after germ-band retraction, variable expression of $a b d-A$ is initiated in the anterior compartment of PS6 in Ual2 embryos but not in wild type. This ectopic expression of $a b d-A$ is presumably responsible for the homeotic transformation observed in adults. The delayed activation of $a b d-A$ in PS6 of $U a l 2$ homozygotes resembles the anterior expansion of $U b x$ expression seen after germ-band retraction of embryos in which $\mathrm{ftz}$ has been expressed indiscriminately under the control of a heat shock promoter (Ish-Horowicz and Gyurkovics 1988; Ish-Horowicz et al. 1989). In this case, however, anterior spread of $U b x$ expression is correlated with loss of the boundary between parasegments 5 and 6 . In $\mathrm{Ual} 2$ embryos, the en stripe at the anterior margin of PS7 generally remains intact, suggesting that activation of $a b d-A$ in PS6 in Ual2 does not depend on loss of a parasegmental boundary. In a previous attempt to explain the $U a l$ phenotype, a model was proposed in which both segmentation defects and homeotic transformations were considered to result from the same primary defect, the widening of $f t z$ stripes (Duncan 1986). Although this model appears to be essentially correct with respect to segmentation defects, several inconsistencies indicate that homeotic transformations do not arise as suggested. These inconsistencies include exceptions (Duncan 1986; I. Duncan, unpubl.) to two important predictions of the model, that homeotic transformations should always be partial in the Ual mutants, and that there should always be a strong correlation between segmentation defects and homeotic transformations. In addition, the model predicts early, rather than delayed, expression of $a b d-A$ in PS6 in Ual homozygotes and makes no provision for why homeotic transformations should occur almost exclusively in PS6.
If stripe widening is not the cause of homeotic transformations in Ual mutants, what is? Two striking differences in $\mathrm{ftz}$ protein expression are evident in $\mathrm{Ual} \mathrm{mu}-$ tants: $f t z$ protein accumulates to higher levels than in wild type, and it persists much longer in development. Because animals carrying extra doses of $\mathrm{ftz}^{+}$show transformations of PS6 to PS8 but do not show marked protein persistence, whereas $U a l$ mutant hemizygotes show only a low frequency of homeotic transformations but show strong protein persistence (D. Mattson and I. Duncan, unpubl.), it seems likely that the cause of the transformations is an excess of $f t z$ protein, not abnormal persistence. One way that increased $f t z$ protein could cause transformations of PS6 to PS8 is if the identities of these parasegments were distinguished by the relative amounts of $f t z$ protein and some other protein present in a gradient in the embryo. Enhancement of homeotic transformations in $\mathrm{Ual}$ heterozygotes by alleles of the gap gene Krüppel (Kr) (Duncan 1986) suggests that $\mathrm{ftz}$ and $K r$ proteins may participate in such a mechanism. $K r$ is expressed at blastoderm in a broad central domain in which protein levels are high centrally and diminished toward the poles (Gaul et al. 1987; Gaul and Jäckle 1989 |. PS6 is defined by the third $f t z$ stripe, which lies in the region of peak $K r$ expression, whereas PS8 is defined by the fourth $\mathrm{ftz}$ stripe, which lies in a region of lower $K r$ expression. An overall increase in the amount of $f t z$ protein, such as occurs in the $U a l$ mutants, could transform PS6 toward PS8 by changing the $f t z$ to $K r$ protein ratio in PS6 to one more like that normally present in PS8. Models of this type can accommodate, but do not explain, the delay in activation of $a b d-A$ in PS6 until after germ-band retraction. The model suggested here raises the possibility that the target of heat shock in causing transformations of PS6 to PS8 (Duncan 1986) is $K r$, or some other gene whose product shows a graded distribution at blastoderm, rather than $f t z$, as suggested originally.

\section{Materials and methods}

\section{Sequence analysis}

Genomic Southern blots were carried out by standard methods (Maniatis et al. 1982). Genomic DNAs from each of the Ual mutants and their wild-type background alleles (Ual2 was induced on a $p^{p} M c p$ chromosome, whereas Ual1 and Ual3 were induced on Canton-S) were restricted with EcoRI, Sau3A, $K p n I+S a l I$ and $X b a I+S a l I$ and Southern blots probed with pDm V61 H3.5 (Weiner et al. 1984), a 3.5-kb HindIII genomic clone that includes the $f t z$ transcribed region. This would have detected rearrangement breakpoints throughout the $f t z$ transcribed and regulatory regions. Genomic libraries from each of the mutants and their wild-type background alleles were constructed in the EMBL3 $\lambda$ vector (Frischauf et al. 1983) and screened in duplicate with probes flanking the $\mathrm{ftz}$ transcription unit to identify clones bearing the complete ftz-coding region. A 2.6-kb PstI-HindIII fragment from each allele was then subcloned into the pEMBL18 + and pEMBL19+ vectors (Dente et al. 1985), and dideoxy DNA sequencing was carried out using the Sequenase system (U.S. Biochemical Corp.) and eight synthetic primers complementary to sites spaced throughout the 
gene. The entire PstI-HindIII subclone was sequenced from one strand, and the region containing the $U a l$ mutations was sequenced from both strands. Homology searches of the NBRF protein data base were conducted with the ProfileSearch and WordSearch programs of the University of Wisconsin Genetics Computer Group software package (Devereux et al. 1984).

\section{Antibody labeling}

Fixation All embryos were fixed with a modification of the two-phase heptane/fixative procedure (Mitchison and Sedat 1983). Embryos were dechorionated in $50 \%$ bleach in water, rinsed in PBSTx (10 mM phosphate, $150 \mathrm{mM} \mathrm{NaCl}, 0.05 \%$ Triton-X 100), and fixed for $30 \mathrm{~min}$ at room temperature with vigorous shaking in $3.2 \mathrm{ml}$ of PMG [ $50 \mathrm{mM}$ PIPES (pH 6.9), 1 $\mathrm{mM} \mathrm{MgSO}_{4}, 2 \mathrm{mM} \mathrm{EGTA]}, 0.8 \mathrm{ml}$ of $37 \%$ formaldehyde, and 4 $\mathrm{ml}$ of heptane. The aqueous phase was replaced with $4 \mathrm{ml}$ of methanol, and the tube was shaken vigorously for $30 \mathrm{sec}$ to remove vitelline membranes. Embryos were then washed four times in methanol and stored at $5^{\circ} \mathrm{C}$ in absolute methanol.

Histochemical staining Embryos were treated for $15 \mathrm{~min}$ in $3 \% \mathrm{H}_{2} \mathrm{O}_{2}$ in methanol to block endogenous peroxidase, rehydrated in PBSTx, and blocked for $2 \mathrm{hr}$ in $5 \%$ powdered milk in PBSTx. Primary antibodies were added in block and incubated for $1.5 \mathrm{hr}$. Embryos were washed three times at $10 \mathrm{~min}$ per wash in PBSTx and incubated with biotinylated secondary antibodies (Vector Laboratories) for $\mathrm{l} \mathrm{hr}$ in block at a dilution of $1: 200$. The washing procedure was repeated, and the embryos were then incubated with streptavidin-HRP (Chemicon Laboratories) for $30 \mathrm{~min}$ in block at a dilution of $1: 200$. After a third wash procedure, the color was developed with $0.25-0.5 \mathrm{mg} / \mathrm{ml}$ diaminobenzidine (Amersham) in $50 \mathrm{mM}$ Tris (pH 7.2), 0.012\% $\mathrm{H}_{2} \mathrm{O}_{2}$, with or without $0.4 \% \mathrm{NiCl}_{2}$ or $\mathrm{CoCl}_{2}$. For double-labeling, embryos were stripped of the initial primary and secondary antibodies by a 5 -min treatment in $0.2 \mathrm{M}$ glycine- $\mathrm{HCl}$ $(\mathrm{pH} 2.5)$ and then reblocked for an additional hour. Embryos were then stained for the second antigen as above.

All embryos were dehydrated from PBS (without Triton X) into $95 \%$ ethanol, followed by $100 \%$ ethanol, and were mounted in Permount (Fisher) containing 30\% methyl salicylate. Embryos were photographed under differential interference contrast or bright-field optics with Polaroid type 55, Kodak Ektachrome 400, or Kodak EKTAR 125 films, using a Zeiss Axiomat photomicroscope or a Photomicroscope III.

The primary antibodies used were as follows: Monoclonal mouse anti-ftz and monoclonal mouse anti-abd- $A$ antibodies were generated in this laboratory (see below). The $f t z$ antibody was used as ascites at a concentration of $1: 500$, and the $a b d-A$ antibody was used as hybridoma culture supernatant at a concentration of $1: 10$. Polyclonal rabbit anti-eve was kindly provided by $M$. Frasch and was used at a concentration of $1: 5000$. Monoclonal mouse anti-en is the mAb 4D9 antibody of Patel et al. (1989b). The mAb 4D9 cell line was obtained from the American Type Culture Collection, and the hybridoma culture supernatant was used at a concentration of $1: 4$.

\section{Western blots}

Half-hour egg collections were made for each genotype and aged until embryos were 2.75 to $3.25 \mathrm{hr}$ old. Embryos were then dechorionated in $50 \%$ bleach in water and washed with PBSTx. To determine the relative synchrony of each genotype, a portion of each collection was observed under the microscope and scored for the percentage of embryos at blastoderm. After dechorionation, embryos were homogenized in SDS lysis buffer
(2.5\% SDS, $60 \mathrm{~mm}$ Tris, $0.005 \%$ bromophenol blue, $10 \%$ glycerol), boiled for $5 \mathrm{~min}$, and stored at $-20^{\circ} \mathrm{C}$. The total protein content of each lysate was then determined by Lowry analysis, and equivalent protein amounts $(\sim 580 \mu \mathrm{g}$ total protein per lane) were run on a $10 \%$ polyacrylamide gel and electroblotted onto nitrocellulose.

$f t z$ protein was detected by use of a rabbit anti-ftz polyclonal antibody (kindly provided by $\mathrm{H}$. Krause). To control for the amounts of protein loaded, a rabbit polyclonal antiserum against Drosophila cytoplasmic myosin (Kiehart and Feghali 1986), provided by Dr. Kathryn Miller, was used. Both antibodies were visualized with ${ }^{125}$ I-labeled protein A (ICN) and quantitated by gamma counting.

\section{Isolation of monoclonal antibodies}

The monoclonal antibodies mAb DMabd-A.1 and mAb DMftz.l were generated by using the following general protocol: BALB/c mice (2-6 months old) were immunized with $\mathrm{ftz}$ and $a b d-A$ proteins produced by the $T 7$ expression system of Studier and Moffatt (1986) (abd-A construct kindly provided by Dr. Shige Sakonju, and $f t z$ construct kindly provided by Dr. Allen Laughon). Mice received an initial injection of $100 \mu \mathrm{g}$ of protein in PBS emulsified $1: 1$ with Freund's complete adjuvant. The mice were rested for 2 weeks and were then given three boosts of $100 \mu \mathrm{g}$ of protein in Freund's incomplete adjuvant at 1 week intervals. Five days after the final boost, serum samples were tested for staining on fixed embryos. Mice giving good serum responses were boosted with $50 \mu \mathrm{g}$ of protein without adjuvant on three successive days, rested for 1 day, and fused on the next day. Spleen cells were fused in the presence of $50 \%$ PEG to SP2/0 myeloma cells, using standard protocols. Hybridoma supernatants were screened 1-2 weeks later on fixed embryos, and positive preclones were cloned by limiting dilution.

Both antibodies isolated in this study are subtype IgG 2a Kappa (isotyped using the ScreenType mouse immunoglobulin isotyping kit, BMB|. Although no epitope mapping has been undertaken, the $f t z$ antibody must recognize an epitope within the amino-terminal $3 / 4$ of the protein, as it stains the $f t z^{\mathrm{Rpl}}$ protein.

\section{In situ hybridization}

In situ hybridization to intact embryos was performed by using the Genius Nonradioactive DNA Labeling and Detection Kit (Boehringer Mannheim). A 2.2-kb PstI-EcoRI DNA fragment was labeled according to kit instructions. Embryos were fixed in paraformaldehyde and hybridized and stained according to the method of Tautz and Pfeifle (1989). Following color development (4-6 hr), embryos were washed thoroughly in PBS + $0.1 \%$ Tween $+20 \mathrm{~mm}$ EDTA, dehydrated stepwise into ethanol, and mounted in Permount.

\section{Embryo injections}

Embryos were injected with cycloheximide (Sigma) at $1 \mathrm{mg} / \mathrm{ml}$ in $5 \mathrm{mM} \mathrm{KCl}$, and $0.1 \mathrm{mM} \mathrm{NaPO}_{4}\langle\mathrm{pH} 6.5\}$ as described by Weir et al. (1988). To ascertain that the dose of inhibitor used was not limiting, one injection series was carried out at $10 \mathrm{mg} / \mathrm{ml}$ cycloheximide. To determine whether $\mathrm{ftz}$ protein degradation is energy dependent, cycloheximide was injected $(1 \mathrm{mg} / \mathrm{ml})$ along with 2-deoxy-D-glucose at $1 \mathrm{M}$ and sodium azide at $0.5 \mathrm{M}$.

Embryos were prepared and injected by standard methods and were then incubated at $25^{\circ} \mathrm{C} 100 \%$ relative humidity for appropriate times, washed off the injection slide in a stream of heptane, and transferred to acid-washed glass screw-cap tubes con- 
taining fixative and heptane, as described above, and shaken vigorously for $30 \mathrm{~min}$ at room temperature. After fixation, embryos were rinsed in PBS, and vitelline membranes were removed manually. Embryos were then transferred to PBSTx, dehydrated into methanol, and stored at $5^{\circ} \mathrm{C}$. Antibody staining was as described above.

\section{Quantitation of embryo staining intensities}

An underlying assumption in our analysis is that the staining intensity of a stripe is proportional to the amount of $f t z$ protein present. Because of variation in staining intensities from day to day, only embryos that were injected and fixed on the same night and stained together with the same reagents for the same length of time were compared. Stained embryos were photographed on a Zeiss Axiomat photomicroscope, using $4 \times 5$-inch Polaroid type $55 \mathrm{film}$. Only one embryo for each data point was photographed. The embryo chosen represented an average staining intensity of the 5-10 embryos that comprised each time point. Negatives were scanned for absolute optical density by use of a Molecular Dynamics 300A Computing Densitometer. For each negative, optical densities were measured for the anterior two stripes, the unlabeled anterior pole, and a region outside the embryo. To correct for background staining, the average optical density for the first two stripes was then subtracted from the optical density value for the anterior pole of the embryo. To normalize these values for slight differences in photographic exposure, each was then divided by the optical density of a region of the negative outside of the embryo. In fact, the optical densities of the anterior pole and of regions outside of the embryo hardly varied, so that qualitatively very similar results were obtained by simply plotting uncorrected stripe optical density values.

\section{Crosses}

All flies were raised on the medium of Lewis $(1960)$ at $25^{\circ} \mathrm{C}$ and $75 \%$ relative humidity. All Ual2 embryos described were from homozygous parents produced by crossing Ual2 $p^{p} \mathrm{cu} \mathrm{Ubx^{1 }}$ $e^{4 / T M 1}$ males to $\operatorname{In}(3 L) P$, Mé Ual2 $p^{p / T M 3}, S b$ Ubx ${ }^{D 105.17} \mathrm{Ser}$ females. (Ubx ${ }^{D 105.17}$ is an EMS-induced $U b x$ allele recovered by I. Duncan.) Although Ual2 homozygotes have low viability, all classes of progeny except homozygous Ual2 escapers die in this cross. Because $f t z^{\mathrm{Rpl}}$ is a recessive lethal, all $R p l$ embryos were collected from heterozygous parents. To avoid the production of gross aneuploids from adjacent segregations, parents were made heterozygous for the $R p l$ translocation and $T(2 ; 3) A n t p^{N s+R C 8}$ (Struhl 1981), a translocation whose breakpoints closely match those of $R p l$. Recovery of the combinations $T(2 ; 3) f t z^{R p l L} A n t p^{N S+R C 8 R}$ and $T(2 ; 3) A n t p^{N s+R C 8 L} f t z^{R p l R}$ confirm that the heterochromatic second chromosome breakpoints of both translocations lie in the same arm.

\section{Acknowledgments}

We are indebted to Tim Karr for discussions and much advice on embryo staining and antibody production. We thank Allen Laughon and Shige Sakonju for generously providing $\mathrm{ftz}$ and $a b d-A$ expression constructs, and Manfred Frasch, Henry Krause, Sean Carroll, and Welcome Bender for providing antibodies. We also thank Javier Lopez for helpful advice on hybridoma production, Michael Welte for instruction in Western blotting, Kathy Miller for advice on embryo injection, Matt Scott for providing $f t z$ genomic clones and advice on DNA sequencing, and Yash Hiromi for providing $f t z / \beta$-gal stocks. Finally, we thank Steve DiNardo, Marty Rechsteiner, Henry
Huang, and Oscar Chilson for helpful discussions and the anonymous reviewers for comments on the manuscript. Our work was supported by a grant from the National Institutes of Health.

The publication costs of this article were defrayed in part by payment of page charges. This article must therefore be hereby marked "advertisement" in accordance with 18 USC section 1734 solely to indicate this fact.

\section{References}

Andrews, P.C., C.D. Minth, and J.E. Dixon. 1982. Immunochemical characterization of a proline endopeptidase from rat brain. J. Biol. Chem. 257: 5861-5865.

Baker, N.E. 1987. Molecular cloning of sequences from wingless, a segment polarity gene in Drosophila: The spatial distribution of a transcript in embryos. EMBO J. 6: 1765-1773.

Campos-Ortega, J.A. and V. Hartenstein. 1985. The embryonic development of Drosophila melanogaster. Springer, Berlin.

Caput, D., B. Beutler, K. Hartog, R. Thayer, S. Brown-Shimer, and A. Cerami. 1986. Identification of a common nucleotide sequence in the $3^{\prime}$-untranslated region of mRNA molecules specifying inflammatory mediators. Proc. Natl. Acad. Sci. 83: $1670-1674$.

Carroll, S.B. and M.P. Scott. 1985. Localization of the fushi tarazu protein during Drosophila embryogenesis. Cell 43: 47-57.

Dearolf, C.R., J. Topol, and C.S. Parker. 1989. Transcriptional control of Drosophila fushi tarazu zebra stripe expression. Genes Dev. 3: 384-398.

Dente, L., M. Sollazzo, C. Baldari, G. Cesareni, and R. Cortese. 1985. The pEMBL family of single-stranded vectors. In DNA cloning (ed. D.M. Glover), vol. 1, pp. 101-107. IRL Press, Oxford and Washington.

Desplan, C., J. Theis, and P.H. O'Farrell. 1988. The sequence specificity of homeodomain-DNA interaction. Cell 54: $1081-1090$.

Devereux, J., P. Haeberli, and O. Smithies. 1984. A comprehensive set of sequence analysis programs for the VAX. Nucleic Acids Res. 12: 387-395.

DiNardo, S. and P.H. O'Farrell. 1987. Establishment and refinement of segmental pattern in the Drosophila embryo: Spatial control of engrailed expression by pair-rule genes. Genes Dev. 1: 1212-1225.

DiNardo, S., J.M. Kuner, J. Theis, and P.H. O'Farrell. 1985. Development of embryonic pattern in $\mathrm{D}$. melanogaster as revealed by accumulation of the nuclear engrailed protein. Cell 43: 59-69.

DiNardo, S., E. Sher, J. Heemskerk-Jongens, J.A. Kassis, and P.H. O'Farrell. 1988. Two-tiered regulation of spatially patterned engrailed gene expression during Drosophila embryogenesis. Nature 332: 604-609.

Duncan, I. 1986. Control of bithorax complex functions by the segmentation gene fushi tarazu of D. melanogaster. Cell 47: 297-309.

- 1987. The bithorax complex. Annu. Rev. Genet. 21: $285-319$.

Edgar, B.A., M.P. Weir, G. Schubiger, and T. Kornberg. 1986. Repression and turnover pattern fushi tarazu RNA in the early Drosophila embryo. Cell 47: 747-754.

Edgar, B.A., G.M. Odell, and G. Schubiger. 1987. Cytoarchitecture and the patterning of fushi tarazu expression in the Drosophila blastoderm. Genes Dev. 1: 1226-1237.

Fagan, J.M., L. Waxman, and A.L. Goldberg. 1986. Red blood cells contain a pathway for the degradation of oxidant-damaged hemoglobin that does not required ATP or ubiquitin. $J$. 
Biol. Chem. 261: 5705-5713.

Fjose, A., W.J. McGinnis, and W.J. Gehring. 1985. Isolation of a homoeo box-containing gene from the engrailed region of Drosophila and the spatial distribution of its transcript. $\mathrm{Na}$ ture 313: 284-289.

Frasch, M. and M. Levine. 1987. Complementary patterns of even-skipped and fushi tarazu expression involve their differential regulation by a common set of segmentation genes in Drosophila. Genes Dev. 1: 981-995.

Frasch, M., T. Hoey, C. Rushlow, H. Doyle, and M. Levine. 1987. Characterization and localization of the even-skipped protein of Drosophila. EMBO I. 6: 749-759.

Frasch, M., R. Warrior, J. Tugwood, and M. Levine. 1988. Molecular analysis of even-skipped mutants in Drosophila development. Genes Dev. 2: 1824-1838.

Frigerio, G., M. Burri, D. Bopp, S. Baumgartner, and M. Noll. 1986. Structure of the segmentation gene paired and the Drosophila PRD gene set as part of a gene network. Cell 47: 735-746.

Frischauf, A.-M., H. Lehrach, A. Poustka, and N. Murray. 1983. Lambda replacement vectors carrying polylinker sequences. J. Mol. Biol. 170: 827-842.

Gaul, U. and H. Jäckle. 1989. Analysis of maternal effect mutant combinations elucidates regulation and function of the overlap of hunchback and Krüppel gene expression in the Drosophila blastoderm embryo. Development 107: 651662.

Gaul, U., E. Seifert, R. Schuh, and H. Jäckle. 1987. Analysis of Krüppel protein distribution during early Drosophila development reveals posttranscriptional regulation. Cell 50: $639-647$

Gergen, J.P. and B.A. Butler. 1988. Isolation of the Drosophila segmentation gene runt and analysis of its expression during embryogenesis. Genes Dev. 2: 1179-1193.

Gronostajski, R.M., A.B. Pardee, and A.L. Goldberg. 1985. The ATP dependence of the degradation of short and long-lived proteins in growing fibroblasts. I. Biol. Chem. 260: 33443349.

Hafen, E., A. Kuroiwa, and W.J. Gehring. 1984. Spatial distribution of transcripts from the segmentation gene fushi tarazu during Drosophila embryonic development. Cell 37: 833841.

Harding, K., C. Rushlow, H.J. Doyle, T. Hoey, and M. Levine. 1986. Cross-regulatory interactions among pair-rule genes in Drosophila. Science 233: 953-959.

Hiromi, Y. and W.J. Gehring. 1987. Regulation and function of the Drosophila segmentation gene fushi tarazu. Cell 50: $963-974$.

Hiromi, Y., A. Kuroiwa, and W.J. Gehring. 1985. Control elements of the Drosophila segmentation gene fushi tarazu. Cell 43: 603-613.

Hochster, R.M. 1963. Hexose and Pentose analogues. In Metabolic inhibitors (ed. R.M. Hochster and J.H. Quastel), vol. I. Academic Press, New York and London.

Howard, K. and P. Ingham. 1986. Regulatory interactions between the segmentation genes fushi tarazu, hairy, and engrailed in the Drosophila blastoderm. Cell 44: 949-957.

Ingham, P.W. and A. Martinez-Arias. 1986. The correct activation of Antennapedia and bithorax complex genes requires the fushi tarazu gene. Nature 324: 592-597.

Ingham, P.W., K.R. Howard, and D. Ish-Horowicz. 1985. Transcription pattern of the Drosophila segmentation gene hairy. Nature 318: 439-445.

Ingham, P.W., D. Ish-Horowicz, and K.R. Howard. 1986. Correlative changes in homeotic and segmentation gene expression in Krüppel mutant embryos of Drosophila. EMBO /.
5: $1659-1665$.

Ingham, P.W., N.E. Baker, and A. Martinez-Arias. 1988. Regulation of segment polarity genes in the Drosophila blastoderm by fushi tarazu and even skipped. Nature 331: 73-75.

Ish-Horowicz, D. and H. Gyurkovics. 1988. Ectopic segmentation gene expression and metameric regulation in Drosophila. Development (suppl.) 104: 67-73,

Ish-Horowicz, D., S.M. Pinchin, P.W. Ingham, and H.G. Gyurkovics. 1989. Autocatalytic $f t z$ activation and metameric instability induced by ectopic $f t z$ expression. Cell 57: 223 232.

Karr, T.L. and T. Kornberg. 1989. fushi tarazu protein expression in the cellular blastoderm of Drosophila detected using a novel imaging technique. Development 105: 95-103.

Kiehart, D.P. and R. Feghali. 1986. Cytoplasmic myosin from Drosophila melanogaster. J. Cell Biol. 103: 1517-1525.

Kilchherr, F., S. Baumgartner, D. Bopp, E. Frei, and M. Noll. 1986. Isolation of the paired gene of Drosophila and its spatial expression during early embryogenesis. Nature 321: $493-499$.

Kornberg, T., I. Sidén, P. O'Farrell, and M. Simon. 1985. The engrailed locus of Drosophila: In situ localization of transcripts reveals compartment-specific expression. Cell 40: $45-53$.

Krause, H.M. and W.J. Gehring. 1989. Stage-specific phosphorylation of the fushi tarazu protein during Drosophila development. EMBO J. 8: 1197-1204.

Krause, H.M., R. Klemenz, and W.J. Gehring. 1988. Expression, modification, and localization of the fushi tarazu protein in Drosophila embryos. Genes Dev. 2: 1021-1036.

Laughon, A. and M.P. Scott. 1984. Sequence of a Drosophila segmentation gene: Protein structure homology with DNAbinding proteins. Nature 310: $25-31$.

Laughon, A., W. Howell, and M.P. Scott. 1988. The interaction of proteins encoded by Drosophila homeotic and segmentation genes with specific DNA sequences. Development (suppl.) 104: 75-83.

Lawrence, P.A. 1987. Pair-rule genes: Do they paint stripes or draw lines? Cell 51: 879-880.

Lawrence, P.A. and P. Johnston. 1989a. Pattern formation in the Drosophila embryo: Allocation of cells to parasegments by even-skipped and fushi tarazu. Development 105: 761-767.

$1989 \mathrm{~b}$. Analysis of function of the pair-rule genes hairy, even-skipped and fushi tarazu in mosaic Drosophila embryos. Development 107: 847-853.

Lawrence, P.A., P. Johnston, P. Macdonald, and G. Struhl. 1987. Borders of parasegments in Drosophila embryos are delimited by the fushi tarazu and even-skipped genes. Nature 328: 440-442.

Lewis, E.B. 1960. A new standard food medium. Drosophila Inf. Serv. 34: 117-118.

1978. A gene complex controlling segmentation in Drosophila. Nature 276: 565-570.

Macdonald, P.M., P. Ingham, and G. Struhl. 1986. Isolation, structure and expression of even-skipped: A second pair-rule gene of Drosophila containing a homeo box. Cell 47: 721734.

Maniatis, T., E.F. Fritsch, and J. Sambrook. 1982. Molecular cloning: A laboratory manual. Cold Spring Harbor Laboratory, Cold Spring Harbor, New York.

Martinez-Arias, A. and P.A. Lawrence. 1985. Parasegments and compartments in the Drosophila embryo. Nature 313: 639642.

Martinez-Arias, A., N.E. Baker, and P.W. Ingham. 1988. Role of segment polarity genes in the definition and maintenance of cell states in the Drosophila embryo. Development 
103: $157-170$.

Mentlein, R. 1988. Proline residues in the maturation and degradation of peptide hormones and neuropeptides. FEBS Lett. 234: 251-256.

Mitchison, T.J. and J. Sedat. 1983. Localization of antigenic determinants in whole Drosophila embryos. Dev. Biol. 99: 261-264.

Moreno, S. and P. Nurse. 1990. Substrates for p34cdc2: In vivo veritas? Cell 61: 549-551.

Nüsslein-Volhard, C. and E. Wieschaus. 1980. Mutations affecting segment number and polarity in Drosophila. Nature 287: 795-801.

Nüsslein-Volhard, C., H. Kluding, and G. Jürgens. 1985. Genes affecting the segmental subdivision of the Drosophila embryo. Cold Spring Harbor Symp. Quant. Biol. 50: 145-154.

Patel, N.H., T.B. Kornberg, and C.S. Goodman. 1989a. Expression of engrailed during segmentation in grasshopper and crayfish. Development 107: 201-212.

Patel, N.H., E. Martin-Blanco, K.G. Coleman, S.J. Poole, M.C. Ellis, T.B. Kornberg, and C.S. Goodman. 1989b. Expression of engrailed proteins in arthropods, annelids, and chordates. Cell 58: 955-968.

Pratt, G., R. Hough, and M. Rechsteiner. 1989. Proteolysis in heat-stressed HeLa cells: Stabilization of ubiquitin correlates with the loss of proline endopeptidase. J. Biol. Chem. 264: $12526-12532$.

Ramsay, G., G.I. Evan, and J.M. Bishop. 1984. The protein encoded by the human proto-oncogene c-myc. Proc. Natl. Acad. Sci. 81: 7742-7746.

Rechsteiner, M. 1987. Ubiquitin-mediated pathways for intracellular proteolysis. Annu. Rev. Cell. Biol. 3: 1-30.

- 1988. Regulation of enzyme levels by proteolysis: The role of PEST regions. Adv. Enzyme Reg. 27: 135-151.

Rechsteiner, M., S. Rogers, and K. Rote. 1987. Protein structure and intracellular stability. Trends Biochem. Sci. 12: 390394.

Rogers, S., R. Wells, and M. Rechsteiner. 1986. Amino acid sequences common to rapidly degraded proteins: The PEST hypothesis. Science 234: 364-368.

Sánchez-Herrero, E., I. Vernós, R. Marco, and G. Morata. 1985. Genetic organization of Drosophila bithorax complex. $\mathrm{Na}$ ture 313: $108-113$.

Shaw, F. and R. Kamen. 1986. A conserved AU sequence from the $3^{\prime}$ untranslated region of GM-CSF mRNA mediates selective mRNA degradation. Cell 46: 659-667.

Struhl, G. 1981. A homoeotic mutation transforming leg to antenna in Drosophila. Nature 292: 635-638.

- 1985 . Near-reciprocal phenotypes caused by inactivation or indiscriminate expression of the Drosophila segmentation gene ftz. Nature 318: 677-680.

Studier, F.W. and B.A. Moffatt. 1986. Use of bacteriophage T7 RNA polymerase to direct selective high-level expression of cloned genes. I. Mol. Biol. 189: 113-130.

Tautz, D. and C. Pfeifle. 1989. A non-radioactive in situ hybridization method for the localization of specific RNAs in Drosophila embryos reveals translational control of the segmentation gene hunchback. Chromosoma 98: 81-85.

Tautz, D., R. Lehmann, H. Schnürch, R. Schuh, E. Seifert, A. Kienlin, K. Jones, and H. Jäckle. 1987. Finger protein of novel structure encoded by hunchback, a second member of the gap class of Drosophila segmentation genes. Nature 327: 383-389.

Watson, D.K., E.P. Reddy, P.H. Duesberg, and T.S. Papas. 1983. Nucleotide sequence analysis of the chicken c-myc gene reveals homologous and unique coding regions by comparison with the transforming gene of avian myelocytomatosis virus
MC29, (4)gag-myc. Proc. Natl. Acad. Sci. 80: 2146-2150.

Weiner, A.J., M.P. Scott, and T.C. Kaufman. 1984. A molecular analysis of fushi tarazu, a gene in Drosophila melanogaster that encodes a product affecting segment number and cell fate. Cell 37: 843-851.

Weir, M.P., B.A. Edgar, T. Kornberg, and G. Schubiger. 1988. Spatial regulation of engrailed expression in the Drosophila embryo. Genes Dev. 2: 1194-1203.

Wilson, T. and R. Treisman. 1988. Removal of poly(A) and consequent degradation of c-fos mRNA facilitated by $3^{\prime} \mathrm{AU}-$ rich sequences. Nature 336: 396-399.

Yoshimoto, T., A.K.M.A. Sattar, W. Hirose, and D. Tsuru. 1987. Studies on prolyl endopeptidase from carrot (Daucus carota): Purification and enzymatic properties. Biochim. Biophys. Acta 916: 29-37. 


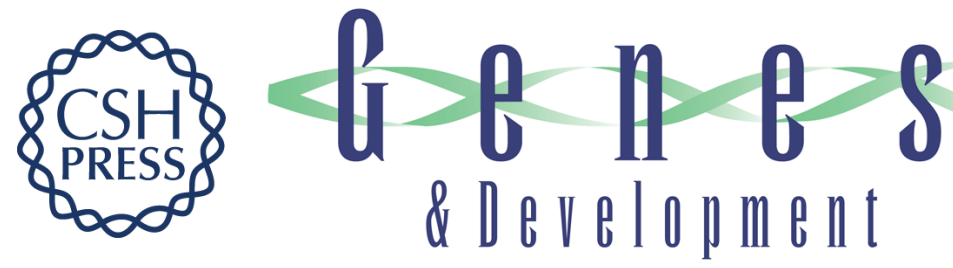

\section{Mutations affecting the stability of the fushi tarazu protein of Drosophila.}

K A Kellerman, D M Mattson and I Duncan

Genes Dev. 1990, 4:

Access the most recent version at doi:10.1101/gad.4.11.1936

References This article cites 78 articles, 25 of which can be accessed free at:

http://genesdev.cshlp.org/content/4/11/1936.full.html\#ref-list-1

License

Email Alerting

Service

Receive free email alerts when new articles cite this article - sign up in the box at the top right corner of the article or click here.

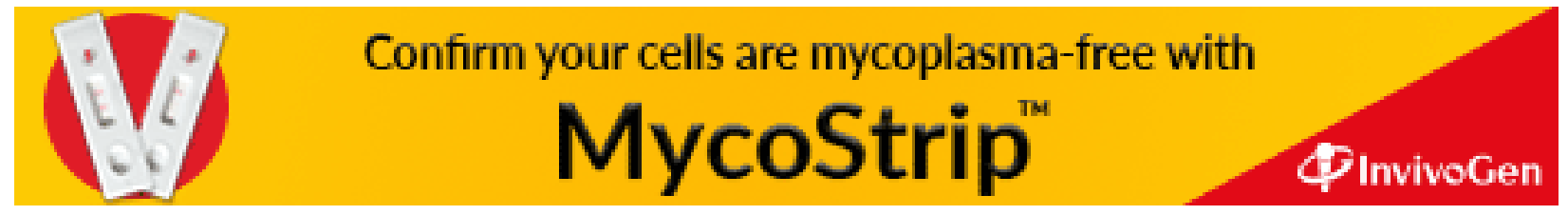

